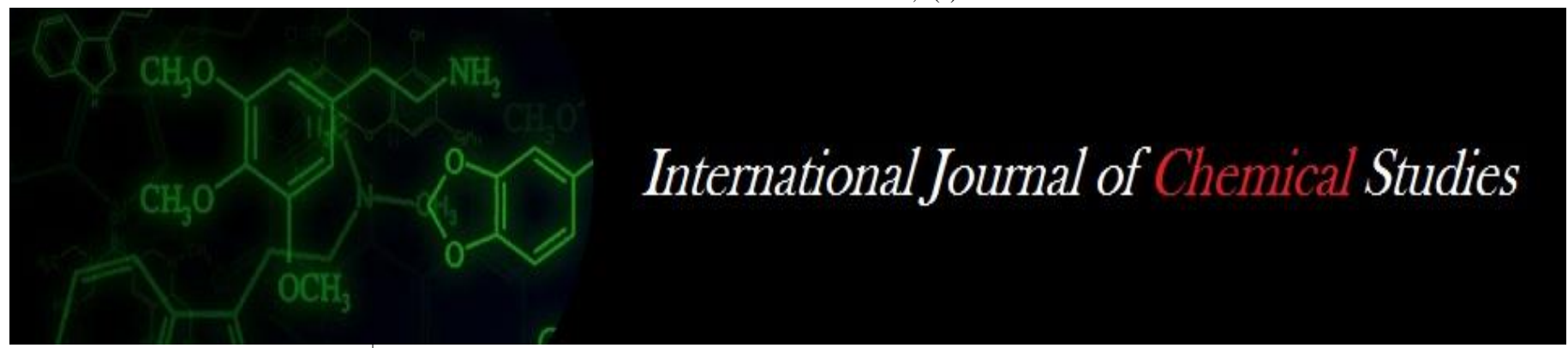

P-ISSN: 2349-8528

E-ISSN: 2321-4902

www.chemijournal.com

IJCS 2020; 8(2): 2955-2957

(C) 2020 IJCS

Received: 01-01-2020

Accepted: 03-02-2020

\section{PD Paralkar}

M.Sc. Student, College of

Agriculture, Latur. Dist. Latur,

Maharashtra, India

\section{SG Patil}

Officer Incharge, Sweet Orange

Research Station, Badnapur,

Maharashtra, India

UM Naglot

Assistant, Professor, COA

Badnapur, Maharashtra, India

\section{Effect of chemicals on fruit quality of mango (Mangifera indica L.) Cv. Kesar}

\section{PD Paralkar, SG Patil and UM Naglot}

DOI: $\underline{\text { https://doi.org/10.22271/chemi.2020.v8.i2at.9200 }}$

\begin{abstract}
The present investigation entitled "Effect of chemicals on fruit retention and quality of mango (Mangifera indica L.) Cv. Kesar" was conducted at Fruit Research Station, Himayatbagh, Aurangabad during the year 2016-17. The objective of this experiment was to improve the quality of mango Cv. Kesar by using NAA, $\mathrm{KNO}_{3}$, Urea and Triacontanol. The experiment was laid out in Randomized Block Design (RBD) with three replication and 13 treatments. Comprising spraying of NAA (@ each 20, 40,60 ppm), $\mathrm{KNO}_{3}$ (@each 2, 4,6\%), Urea (@ each 1, 1.5,2\%), Triacontanol (@ each 100, 300, 500 ppm) and control. The observations on different characters of fruit Viz, per cent of total soluble solids (TSS), per cent of Acidity, per cent of reducing sugar, per cent of non-reducing sugar, per cent of total sugar. Were recorded.

The total soluble solid (TSS) was maximum in treatment T3 NAA @ 40 ppm. The minimum acidity was recorded under treatment $\mathrm{T}_{4}$ NAA @ 60 ppm The maximum reducing sugar was recorded under treatment $\mathrm{T}_{5} \mathrm{KNO}_{3} @ 2$ per cent. The maximum non-reducing sugar was recorded under treatment $\mathrm{T}_{6}$ $\mathrm{KNO}_{3} @ 4$ per cent. The maximum total sugar was recorded under treatment $\mathrm{T}_{5} \mathrm{KNO}_{3} @ 2$ per cent.
\end{abstract}

Keywords: Tricontanol, TSS, NAA, acidity

\section{Introduction}

Mango (Mangifera indica L.) is the king of fruits in India and got a unique position in Indian Horticulture. It is native to India (Indo Burma region). Botanically mango belong to family Anacardiaceae and cultivated mango belongs to Mangifera indica species and wild mango belongs to Mangifera sylvatica and Mangifera khaisana are said to be exist in India.

The mango fruit has been in cultivation in Indian continent for well over 4000 years and has been the favorite of the kings and commoners because of its nutritive value, taste, attractive fragrance and health promoting qualities and now it is recognized as one of the best fruits in the world market.

Mango fruit is used in all its stages of development. The unripe fruit is used for making pickles and chutney. Ripe fruit is mainly used for table purpose and is partly converted into squash, jam, preserves, mango leather and amchur. There is also scope for diversification by making other products likes mango bar, mango jelly and mango ice-cream.

Mango is not only delicious but also full of nutritional value. It is high in beta-carotene, a precursor of vitamin-A and is a rich source of the vitamin-C. The ripe mangoes are reported to have 83.46 - $86.70 \%$ moisture, $0.82 \mathrm{~g}$ protein, $0.38 \mathrm{~g}$ fat, $14.98 \mathrm{~g}$ carbohydrate, $11 \mathrm{mg}$ calcium, $14 \mathrm{mg}$ phosphorus, $0.16 \mathrm{mg}$ iron, 0.135 - 1.872 Vitamin-A (mg/100g $\beta$-Carotene), $0.038 \mathrm{~g} / 100 \mathrm{~g}$ riboflavin and $36.4 \mathrm{mg} / 100 \mathrm{~g}$ ascorbic acid, 12.0-23.0 TSS ( ${ }^{0}$ Brix) and 0.12$0.38 \%$ acidity.

The total area under cultivation of mango in India is 2273 (000 ha) and production is around 19218 (000MT) according to NHB (2016-2017). In India states Andhra Pradesh, Karnataka, Gujarat, Maharashtra, Tamil Nadu, Chhattisgarh, Bihar and Uttar Pradesh are the leading in production of mango.

Kesar is a leading variety of Gujarat with a red blush on the shoulders. It is a superior chance seedling of Junagarh but resembles in nature with South-Indian mangoes. It has been observed that, a large area is under cultivation of this variety in Maharashtra particularly in Marathwada. Quality is influenced by several factors including nutritional and environmental factors. Imbalanced fertilization is considered to be one of the major contributing factors for the low productivity.
Corresponding Author: PD Paralkar M.Sc. Student, College of Agriculture, Latur. Dist. Latur, Maharashtra, India 
Marathwada region is famous for mango plantation mostly of seedling origin. It is extensively grown in almost all districts of Marathwada region particularly Aurangabad, Beed and Nanded district. The orchard of Himayatbagh is the collection of mango made by the Nizam Among these all varieties of mango, Kesar are high yield potential, almost regular bearer, mid-season variety, having good consumer acceptance, attractive shape, size, saffron colored pulp and very good keeping quality. In light of the views mentioned above, the present study "Effect of chemicals on fruit quality of mango (Mangifera indica L.) Cv. Kesar" was taken up under the agro climatic conditions prevailing at Fruit Research Station, Aurangabad hence considering the need, the present investigation study to improve the fruit quality of mango $\mathrm{Cv}$. Kesar by using NAA, $\mathrm{KNO}_{3}$, Urea and Triacontanol.

\section{Materials and Methods}

The present investigation was conducted during 2016-2017 on grafted mango cultivars grown at mango orchard, Fruits Research Station Aurangabad. Aurangabad is situated at $19^{0}$ and $20^{\circ}$ North latitude and $74^{\circ}$ and $76^{\circ}$ East longitude and altitude 409 meter above mean sea level. The climate is generally dry for eight months of the year and wet during south-west monsoon season. The mean rainfall is approximately $662 \mathrm{~mm}$ and is received from June to September. Rainfall is not well distributed in all the parts of district and year. The maximum temperature in summer month goes up to $41.6{ }^{\circ} \mathrm{C}$. The cold weather commences from the middle of November when temperature starts falling and minimum temperature goes down up to $10{ }^{0} \mathrm{C}$. Thus Aurangabad is fairly cool in winter and sufficiently hot in summer, the mean relative humidity ranges from 12 to 90 per cent.

The orchard was established by procuring uniform mango graft of Kesar, Fruit Research Station, Aurangabad during 2008. The trees were planted at spacing 5 X $5 \mathrm{~m}$. These grafts were maintained with uniform horticultural practices. Out of above Cv. Kesar was selected to study "Effect of chemicals on fruit quality of mango (Mangifera indica L.)". Experiment was laid out in Randomized Block Design with three replications and thirteen treatments these are, $\mathrm{T}_{1}$ ( control), $\mathrm{T}_{2}$ (NAA@ 20ppm), T3 (NAA@40ppm), T4(NAA@60ppm)., T5 $\left(\mathrm{KNO}_{3} @ 2 \%\right), \quad \mathrm{T}_{6}\left(\mathrm{KNO}_{3} @ 4 \%\right), \quad \mathrm{T}_{7}\left(\mathrm{KNO}_{3} @ 6 \%\right)$, $\mathrm{T}_{8}$ (Urea,@1\%,) T $\mathrm{T}_{9}$ (Urea@1.5\%), $\mathrm{T}_{10}$ (Urea@2\%), $\mathrm{T}_{11}$ (Triacontanol@100ppm), $\quad \mathrm{T}_{12}$ (Triacontanol@300ppm), 13(Triacontanol@500ppm).

The mango fruits were harvested on the basis of the development of fruits size and maturity indices in two pickings and fruits were randomly sampled from the first picking (peak harvest) and utilized for qualitative estimations. Fruits were allowed to ripen by embedding in newspaper and paddy straw. After ripening the quality parameters were studied.

\section{Total soluble solids (\%)}

After harvest fully ripe mango fruit cut with the help of knife and from this pulp of mango fruits, 2 to 3 drops of mango juice were taken on hand refractometer. The total soluble solids was recorded by using hand refractometer and expressed in \%. The average was computed for each treatment and given in per cent.

\section{Acidity (\%)}

The titrable acidity of the fruit juice was determined. For this $10 \mathrm{ml}$ of juice was titrated against $0.1 \mathrm{~N} \mathrm{NaOH}$ using phenolphthalein as an indicator. The per cent acidity of the juice was expressed as citric acid in gram in $100 \mathrm{~g}$ of fruit juice by using following formula.

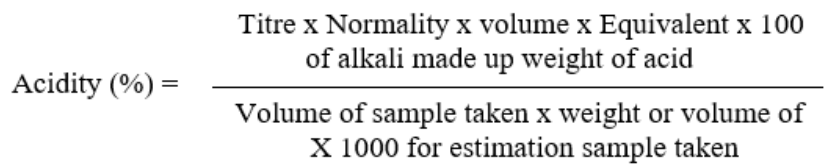

\section{Reducing Sugar (\%)}

Reducing sugar is determined by Lane and Eynon method (1960) in a known weight of composite sample using lead acetate for precipitation (clarifying) of the extraneous material and potassium oxalate is to remove excess of lead (deleading). Reducing sugar of the lead free aliquots is estimated by titrating against boiling standardized Fehling's solution (mixture) using methylene blue as an indicator. Total invert sugar was estimated by the same method in a solution of hydrolysed sucrose (after acid hydrolysis) with concentrated $\mathrm{HCl}$ followed by neutralization of excess acid with $\mathrm{NaOH}$.

$\mathrm{Mg}$ of invert sugar $\mathrm{x}$ dilution $\mathrm{x} 100$

$$
\text { Reducing Sugar }(\%)=\frac{\text { Titre } \mathrm{x} \text { Volume of sample taken } \mathrm{x} 100}{.00}
$$

\section{Non-reducing sugar (\%)}

The difference in percentage between total sugar and reducing sugar was taken for the estimation of non-reducing sugar.

Non reducing sugar $\%=$ Total sugar $(\%)$ - Reducing sugar $(\%)$

\section{Total sugar $(\%)$}

For estimation of total sugar, $20 \mathrm{ml}$ of fruit juice solution was taken in a beaker and $5 \mathrm{ml}$ of concentrated HCI was added and then the solution was boiled on water both for five minutes for the hydrolysis to convert the non- reducing sugar in to reducing sugar. After cooling, the excess of acid was neutralised by sodium carbonate solution. The solution was transferred in a $100 \mathrm{ml}$. volumetric flask and volume was made up to mark by adding distilled water. This solution was taken in a burette and titrated with the Fehling's solution "A" and "B" similar as was done in reducing sugar. The total sugar in percentage was calculated with the help of following formula.

$$
\text { Total sugar }(\%)=\frac{1.25}{\text { Burette reading }} \times 100
$$

\section{Results and Discussion}

Effect of chemicals on fruit quality of mango Cv. Kesar was studied and experiment results are presented in appropriate headings. Mean values obtained from all the observation for each character are presented in form of tables

\section{TSS (\%)}

The maximum TSS (17.95\%) was noticed in treatment $\mathrm{T}_{3}$ NAA $40 \mathrm{ppm}$, which was at par with treatment $\mathrm{T}_{2}$ NAA 20 ppm (17.00\%) and $\mathrm{T}_{13}$ triacontanol $500 \mathrm{ppm}$ (16.94\%). Whereas, minimum TSS $(15.58 \%)$ was observed in treatment $\mathrm{T}_{1}$ (control). The effect of different chemicals on quality characters of mango viz., total soluble solid, reducing sugar and total sugar was found to be significant. While, titrable acidity and non-reducing sugar found non-significant.

As per the results from present investigation, statistically maximum TSS $(17.95 \%)$ was noticed in treatment $\mathrm{T}_{3}$-NAA 
$40 \mathrm{ppm}$. The experiment revealed the beneficial role of chemicals tested on increasing the TSS \% in mango $\mathrm{Cv}$.
Kesar. Similar results found by Ghosh et al. (2009) ${ }^{[1]}$ in aonla.

Table 1: Effect of spraying of chemicals on TSS (\%) and Acidity (\%) chemicals on Reducing sugar (\%), Non-reducing sugar (\%) and Total sugar $(\%)$ of mango

\begin{tabular}{|c|c|c|c|c|c|c|}
\hline Sr. No. & Treatment details & TSS (\%) & Acidity (\%) & Reducing sugar $(\%)$ & Non-reducing sugar (\%) & Total sugar $(\%)$ \\
\hline $\mathrm{T}_{1}$ & Control & 15.58 & 0.24 & 3.17 & 7.95 & 11.12 \\
\hline $\mathrm{T}_{2}$ & NAA@20ppm & 17.00 & 0.26 & 3.45 & 8.29 & 11.74 \\
\hline $\mathrm{T}_{3}$ & NAA@40ppm & 17.95 & 0.24 & 3.23 & 8.05 & 11.28 \\
\hline $\mathrm{T}_{4}$ & NAA@60ppm & 16.73 & 0.23 & 3.59 & 7.90 & 11.49 \\
\hline $\mathrm{T}_{5}$ & $\mathrm{KNO}_{3} @ 2 \%$ & 16.52 & 0.25 & 3.80 & 8.57 & 12.37 \\
\hline $\mathrm{T}_{6}$ & $\mathrm{KNO}_{3} @ 4 \%$ & 16.31 & 0.26 & 3.71 & 8.65 & 12.36 \\
\hline $\mathrm{T}_{7}$ & $\mathrm{KNO}_{3} @ 6 \%$ & 16.39 & 0.25 & 3.30 & 8.07 & 11.37 \\
\hline $\mathrm{T}_{8}$ & Urea@1\% & 15.60 & 0.27 & 3.21 & 8.00 & 11.21 \\
\hline $\mathrm{T}_{9}$ & Urea@1.5\% & 15.94 & 0.26 & 3.24 & 8.04 & 11.28 \\
\hline $\mathrm{T}_{10}$ & Urea@2\% & 15.88 & 0.25 & 3.33 & 8.31 & 11.64 \\
\hline $\mathrm{T}_{11}$ & Triacontanol@100ppm & 16.00 & 0.24 & 3.27 & 8.36 & 11.63 \\
\hline $\mathrm{T}_{12}$ & Triacontanol@300ppm & 16.50 & 0.26 & 3.46 & 8.46 & 11.92 \\
\hline $\mathrm{T}_{13}$ & Triacontanol@500ppm & 16.94 & 0.24 & 3.51 & 8.40 & 11.91 \\
\hline \multicolumn{2}{|c|}{\begin{tabular}{|r|} 
S.E.m \pm \\
\end{tabular}} & 0.34 & 0.01 & 0.08 & 0.44 & 2.28 \\
\hline & $\mathrm{CD}$ at $5 \%$ & 1.01 & NS & 0.24 & NS & 0.82 \\
\hline
\end{tabular}

\section{Acidity (\%)}

The minimum acidity $(0.23 \%)$ was recorded under treatment $\mathrm{T}_{4}$ (NAA 60 ppm.). The maximum acidity $(0.27 \%)$ was recorded under treatment $\mathrm{T}_{8}$ (urea $1 \%$ ) However, remarkable difference was not observed among all the treatment included under this investigation for this attribute. Hence, the treatment was statistically non-significant.

\section{Reducing sugar $(\%)$}

The maximum reducing sugar $(3.80 \%)$ was significantly increased in treatment $\mathrm{T}_{5} \mathrm{KNO}_{3} 2 \%$, which was at par with treatment $\mathrm{T}_{6} \quad \mathrm{KNO}_{3} \quad 4 \%(3.71 \%)$ and $\mathrm{T}_{4}$ NAA $60 \mathrm{ppm}$ $(3.59 \%)$. Whereas, minimum reducing sugar $(3.17 \%)$ was observed in treatment $\mathrm{T}_{1}$ (control). The data revealed that, the maximum reducing sugar $(3.80 \%)$ and total sugar $(12.37 \%)$ was noticed in treatment $\mathrm{T}_{5}-\mathrm{KNO}_{3} 2 \%$. This might be due to potassium reduces respiration, preventing energy losses through maintaining turgor pressure and reduces water loss in fruits which helps in improving the shelf life of fruits. The experiment revealed the beneficial role of chemicals tested on increasing the reducing sugar in mango $\mathrm{Cv}$. Kesar. Similar results found by Patoliya et al. (2017) ${ }^{[2]}$ in mango.

\section{Non-reducing sugar (\%)}

The maximum non-reducing sugar $(8.65 \%)$ was recorded under treatment $\mathrm{T}_{6}\left(\mathrm{KNO}_{3} 4 \%\right)$. The minimum non-reducing sugar $(7.95 \%)$ was recorded under treatment $\mathrm{T}_{1}$ (control). However, remarkable difference was not observed among all the treatment included under this investigation for this attribute. Hence, the treatment was statistically nonsignificant The titrable acidity and non-reducing sugar were not influenced by the different treatment. The remarkable difference was not observed among all the treatments included under this investigation for this attribute. Hence, the treatments were statistically non-significant at this stage. Similar results found by Saha et al. (2017) ${ }^{[3]}$ in mango.

\section{Total sugar $(\%)$}

The maximum total sugar $(12.37 \%)$ was significantly increased in treatment $\mathrm{T}_{5}\left(\mathrm{KNO}_{3} 2 \%\right)$, which was at par with treatment $\mathrm{T}_{6} \mathrm{KNO}_{3} 4 \%(12.36 \%), \mathrm{T}_{12}$ triacontanol $300 \mathrm{ppm}$ (11.92\%), $\mathrm{T}_{13}$ triacontanol $500 \mathrm{ppm}(11.91 \%), \mathrm{T}_{2}$ NAA 20 ppm (11.74\%), $\mathrm{T}_{10}$ urea $2 \%(11.64 \%)$ and $\mathrm{T}_{11}$ triacontanol
100 ppm $(11.63 \%)$. Whereas, minimum total sugar $(11.12 \%)$ was observed in treatment $\mathrm{T}_{1}$ (control).

\section{References}

1. Ghosh SN, Bera B, Roy S, Kundu A, Dutta, Roy SK. Effect of nutrients and plant growth regulators on fruit retention, yield and physicochemical characteristics in aonla Cv. NA-10. J Hortl. Science. 2009; 4(2):164-166.

2. Patoliya RM, Tandel BM, Ahir U, Patil SJ, Chudhari H. Response of foliar spray of different chemicals on yield and quality of Dashehari mango under ultra-high density plantation. International Journal of chemical studies. 2017; 5(4):1495-1497.

3. Saha DP, Jha KK, Sengupta S, Misra S, Kumar R. Effect of chemicals on yield and quality of mango $\mathrm{Cv}$. Mallika. International Journal of Science, Environment and Technology. 2017; 6(2):1512-1515. 